\title{
НЕГАТИВНИЙ ВПЛИВ ХІМІЧНИХ ЧИННИКІВ НА МЕДИЧНУ СЕСТРУ В УМОВАХ ЛІКУВАЛЬНОГО ЗАКЛАДУ ТА ЗАХОДИ ЩОДО ЇХ ПРОФІЛАКТИКИ
}

\author{
В. В. Литвинюк
}

Вінницький базовий медичний коледж ім. акад. Д. К. Заболотного

У статті розглянуто вплив хімічних речовин на здоров'я медичних працівників середнњої ланки різних клінічних закладів та заходи щодо їх профілактики.

\section{THE NEGATIVE INFLUENCE OF CHEMICAL FACTORS ON THE NURSE IN A MEDICAL ESTABLISHMENT AND MEASURES FOR THEIR PREVENTION}

\author{
V. V. Lytvynyuk \\ Vinnytsia Basic Medical College by acad. D. K. Zabolotnyi
}

The article considers the influence of chemical substances on the health of middle-level medical staff of different clinical institutions and measures for their prevention.

Вступ. Здоров'я та безпечні умови праці медичної сестри на робочому місці в останні роки набули особливого значення. Деякі групи медичних працівників середньої ланки в процесі професійної діяльності можуть піддаватися дії багатьох чинників, небезпечних для здоров'я. Серед таких факторів, які можуть істотно негативно вплинути на стан здоров'я медичного персоналу, одне з перших місць посідають хімічні речовини. До них належать дезінфікуючі засоби, антисептики, детергенти, окисники, медикаментозні препарати. Всі вони можуть мати токсичний вплив на організм людини. Причини такого впливу криються у недотриманні основних правил безпеки медичного персоналу, недостатньому вивченню інструкцій із їх застосування та неналежному використанню захисного одягу. Тривалий професійний контакт з різними лікарськими речовинами, мийними і дезінфікуючими засобами, частіше за все з антибіотиками та цитостатиками, може призвести до певних захворювань.

Основна частина. Основними напрямками діяльності медичних сестер у лікувально-профілактичних закладах є дотримання санітарно-протиепідемічного, санітарно-гігієнічного режиму, застосування лікарських речовин, здійснення обробки ранових поверхонь тощо. Така діяльність передбачає використання хімічних речовин, які можуть спричиняти токсичний

(อ) В. В. Литвинюк, 2015 вплив на здоров'я медичного працівника. В основі професійної патології у медичних сестер $є$ передусім алергічна дія дезінфектантів та антисептиків, а також деяких лікарських речовин, особливо антибіотиків. Останні викликають порушення імунітету, що сприяє розвитку дисбактеріозу та іншої патології [1]. Клінічно це проявляється змінами з боку шкірних покривів, внутрішніх органів і нервової системи. Також для медичного персоналу, що має безпосередній контакт із медикаментами та агресивними речовинами, характерні хвороби верхніх дихальних шляхів. Це насамперед зумовлено наявністю в повітрі виробничих приміщень багатокомпонентного медикаментозного пилу і парів агресивних реагентів, що мають сенсибілізувальні властивості та негативно діють на органи дихання, що проявляється у вигляді алергічного нежитю, кашлю, підвищення температури та інших симптомів. Шкірні прояви відрізняються великою варіабельністю та поліморфізмом, реєструються, як правило, у вигляді дерматитів, екземи, кропив'янки тощо. Зміни з боку внутрішніх органів виражаються у вигляді бронхітів і бронхіальної астми, хронічних колітів, міокардитів тощо. Патологія нервової системи проявляється у вигляді вегетосудинної дистонії, сенсорної поліневралгії.

Хімічні препарати, які використовують для знезараження, передстерилізаційного очищення, стерилі- 
зації та дезінфекції виробів медичного призначення мають різний ступінь місцевої і загальної токсичної дії [2]. їх виготовляють у рідкому, порошкоподібному та таблетованому вигляді, що має важливе значення для приготування робочих розчинів різних концентрацій. Такі речовини в обов'язковому порядку мають бути зареєстровані та занесені до Державного реєстру дезінфекційних засобів і тільки тоді можуть застосовуватись в лікувально-профілактичних закладах України [3].

Несприятливими факторами гігієнічних умов праці процедурних і постових медичних сестер закладів охорони здоров'я $є$ постійний контакт їх з лікарськими засобами, серед яких переважають антибактеріальні препарати, вітаміни, анальгетики тощо. Часто спостерігається зв'язок між забрудненням повітря цими речовинами і захворюваністю шкірних покривів у середнього медичного персоналу. Рівень ії залежить від способу введення хворим медикаментів і від проведених маніпуляцій, що передбачають приготування розчинів лікарських препаратів, заповнення шприців, крапельниць, а також способів обробки інструментарію. Найбільшою потенційною небезпекою для здоров'я медичних сестер $є$ робота в аерозольноінгаляційних і процедурних кабінетах, де застосовуються високоактивні медикаменти. Надходження аерозолів, медикаментів чи продуктів їх розпаду в повітря лікарняного середовища відбувається при проведенні ін'єкцій, вливань, аерозольних інгаляцій, а також при митті та стерилізації медичного інвентарю, забрудненого ліками. Наприклад, під час витіснення бульбашок повітря зі шприца через ін'єкційну голку в ділянці дихання медичної сестри утворюються полідисперсні аерозолі, що потрапляють в дихальні шляхи. В наслідок таких дій вміст антибіотика в повітрі процедурного кабінету при багаторазових маніпуляціях може перевищувати гігієнічні норми [1, 2].

Медичні сестри, які працюють в онкологічних відділеннях, щодня мають справу з величезним спектром хімічних речовин, зокрема із цитостатиками. На жаль, багато з них розглядають ці препарати тільки як фактори, зумовлені специфікою професії, не усвідомлюючи небезпеки, які мають ці речовини, особливо віддалені результати їх дії. І хоча на сьогодні системний вплив цитостатичних препаратів на медичний персонал вивчено мало, враховуючи фармакологічні властивості, їх потрібно вважати потенційно небезпечними. Відомі реакції у вигляді запальних процесів слизових оболонок, шкірні пігментації і дерматити, виразки рогівки при потраплянні окремих препаратів на слизову очей, порушення репродуктивної функції та ін. Все це робить пріоритетним організацію захисних заходів щодо мінімізації шкідливого впливу цитостатичних препаратів на організм медичних працівників [4].

Виконуючи свої професійні обов'язки, медична сестра для дотримання правил особистої гігієни використовує такі хімічні речовини, як спиртовмісні антисептики та детергенти, які мають здатність негативно впливати на слизові оболонки та шкірні покриви, викликаючи їх подразнення, пересушування, розтріскування з подальшим можливим виникненням дерматиту та екземи [5].

Враховуючи все вищеназване, ми вирішили провести опитування середнього медичного персоналу 3 різних лікувальних закладів з метою вияснити, який відсоток медичних сестер спостерігають негативний вплив хімічних речовин на свій організм у процесі виконання ними своїх професійних обов'язків, визначити, які саме прояви негативного хімічного впливу вони відчувають та з'ясувати, чи має медичний персонал достатньо інформації про заходи профілактики професійних захворювань. 3 цією метою було складено анкету - опитувальник. Всього було опитано 85 медичних сестер з різних за профілем лікувальних закладів м. Вінниці.

Всі опитані медичні працівники були жіночої статі віком від 20 до 45 років (середній вік $(32 \pm 10,2)$ року, що за класифікацією ВоОз належить до молодого віку.

Згідно з рисунком 1, серед опитаних медичних сестер 40 (47,0 \%) працювали в хірургічному відділенні, 13 (15,2\%) - в терапевтичному, 20 (23,5\%) в психіатричному, 4 (4,7 \%) - у відділенні реанімації, 5 (5,8 \%) - у дитячому та 3 (3,5\%) - у централізованому стерилізаційному відділенні.

Зі слів опитаних, негативну дію хімічних чинників на свій організм вже відчули більшість - 57 (67,1 \%) медичних сестер, не відчули такого впливу 28 (32,9\%) (рис. 2).

Негативна дія хімічних чинників на здоров'я медичних працівників проявлялася у 5 (8,8 \%) опитаних у вигляді головокружіння, у $12(21,0 \%)$ - головного болю, у $16(28,0 \%)$ - в нападах роздратованості, у 7 (12,2\%) сльозотечі, у 12 (21,0\%) - ураження шкіри та слизових оболонок та 5 (8,8 \%) осіб мали інші прояви (рис. 3).

При опитуванні медичних сестер про заходи профілактики шкідливого впливу хімічних чинників було встановлено, що лише 39 (45,9\%) осіб з метою захисту використовують захисний одяг, 41 (48,2 \%) дотримуються інструкцій та інших нормативних актів і наказів, 

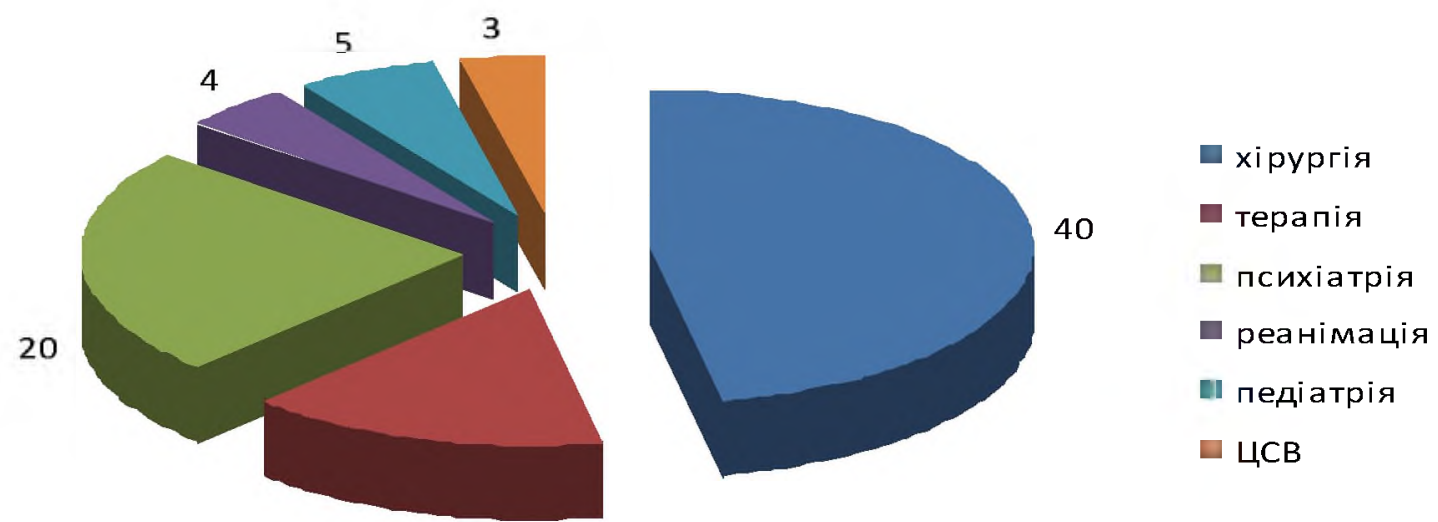

13

PUс. 1. Кількість опитаних медичних сестер за місцем роботи.

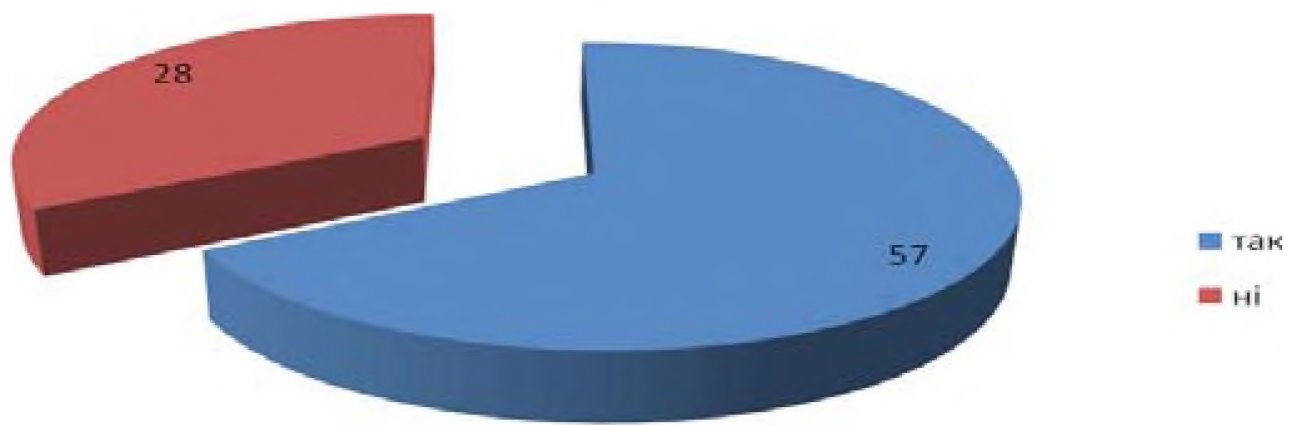

PUC. 2. Суб'єктивне відчуття негативної дії хімічних чинників на організм.

$6(7,0 \%)$ з метою профілактики ведуть активний спосіб життя та $6(7,0 \%)$ зверталися до лікаря за допомогою з приводу професійного захворювання (рис. 4).

Для попередження або зменшення негативного токсичного впливу хімічних факторіву лікувальних закладах, у процесі виконання своїх професійних обов'язків, середній медичний персонал має дотримуватись таких основних заходів безпеки, що передбачено посадовими інструкціями та інструкціями з техніки безпеки:
1) до роботи з дезінфекційними препаратами допускаються особи, не молодші 18 років, які пройшли відповідний інструктаж щодо обов'язків, техніки безпеки, заходів профілактики випадкових отруєнь. Відповідальною за інструктаж $є$ спеціально призначена головним лікарем особа;

2) особи, які мають підвищену чутливість до хімічних засобів, щозастосовуютьсяв лікувально-профілактичному закладі, усуваються від роботи з ними;

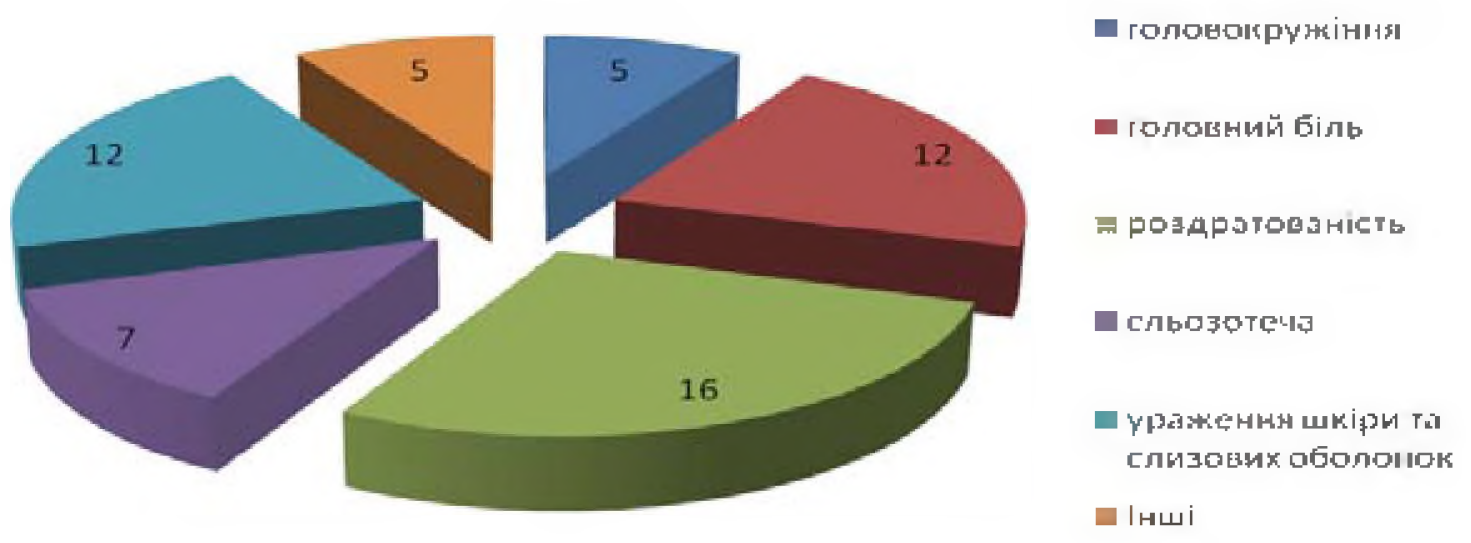

PUC. 3. Прояви негативного впливу хімічного чинника. 


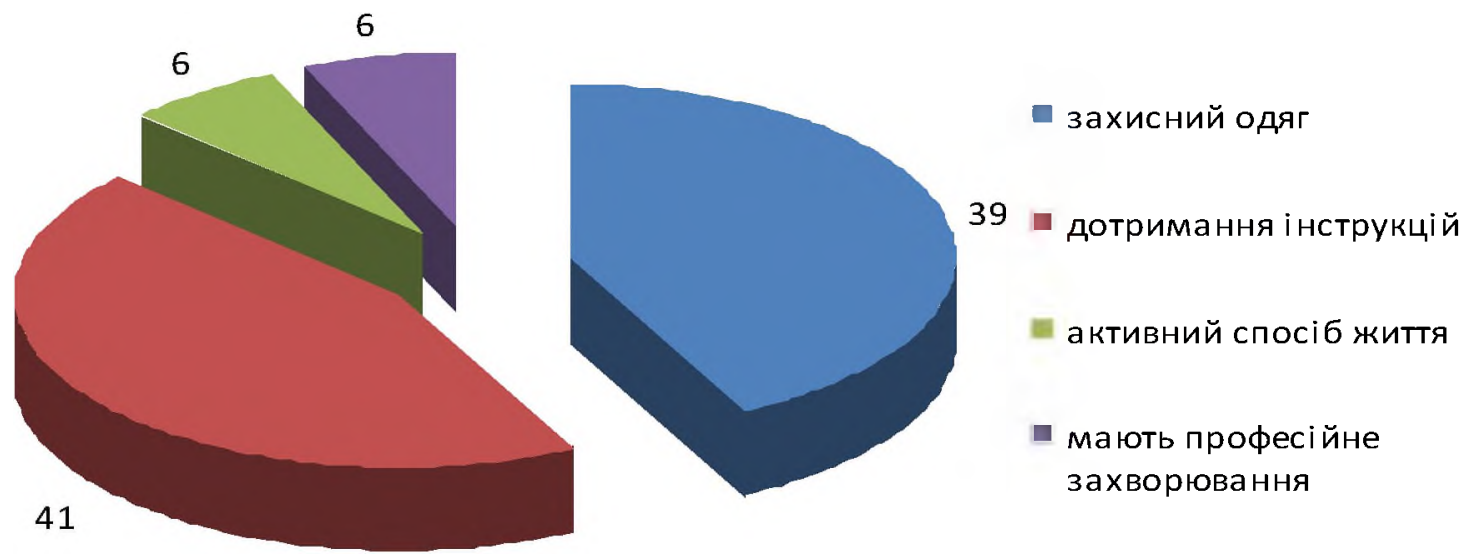

РЧС. 4. Заходи профілактики хімічного впливу.

3) обробка предметів догляду в розчинах дезінфекційних засобів, передстерилізаційна очистка і стерилізація виробів медичного призначення хімічними засобами здійснюють у спеціально відведених приміщеннях, обладнаних припливно-витяжною вентиляцією;

4) робочі розчини дезінфекційних засобів готують у добре провітрюваних приміщеннях. Зберігають розчини і витримують у них предмети, що підлягають обробці, у щільно закритих ємностях;

5) запаси дезінфекційних препаратів зберігають у місцях, не доступних для загального користування, у темному посуді, у сухому неосвітленому прохолодному приміщенні [6]. Усі дезінфекційні засоби і розчини повинні мати етикетки із зазначенням назви, концентрації, дати виготовлення і терміну придатності;

6) певною мірою безпека від впливу хімічних чинників досягається завдяки використанню захисного одягу, який зменшує контакт шкіри з токсичними ре-

\section{ЛІТЕРАТУРА}

1. Салманов А. Гігієнічні умови праці медичного персоналу / А. Салманов // Практика управління медичним закладом. - 2012. - № 12. - С. 22-30.

2. Капцов В. А. Праця і здоров'я медичних працівників як проблема медицини праці / В. А. Капцов // Медична допомога, - 2000, - № 2.

3. Державна санітарно-епідеміологічна служба України [Електронний ресурс] : офіційний веб-сайт. - Режим доступу : http://www.dsesu.gov.ua/ua/normativna-pravovabaza/bazi-ta-r6.

4. Асоциация медицинских сестёр Башкортостана. Безопасность при работе с цитостатиками [Электронный ресурс]. - Режим доступу: http://medsestrarb.ru/obuchenie/ човинами. Захисний одяг включає рукавички, халат, фартух, захисні окуляри, закрите взуття, маску $[7,8]$;

7) використання, зберігання цитостатиків та антибактеріальних препаратів має здійснюватись в спеціалізованих приміщеннях, оснащених витяжними шафами, механічними вентиляціями.

Висновки. В умовах швидкого розвитку хімічної та фармацевтичної промисловості суттєво зросла кількість хімічних речовин, які мають здатність спричиняти не тільки лікувальний ефект на пацієнта, а і здійснювати негативний вплив на медичних працівників середньої ланки при систематичному їх використанні. Основною умовою забезпечення безпеки медичних сестер $є$ дотримання інструкцій щодо застосування таких речовин, відповідних умов їх зберігання, використання захисного одягу, вчасне проходження медичних оглядів, дотримання наказів та нормативних документів виданих Міністерством охорони здоров'я України.

czitostatiki-dezaktivacziya.html eestri/file/599-derzhavnyireiestr-dezinfektsiinykh-zasobiv-za-1-6-misiatsi-2015-roku

5. Антисептичні та дезінфікуючі засоби [Електронний ресурс]. - Режим доступу : http://antyseptyky.com/tag/ zasobi/page/3/

6. Химические факторы риска в ЛПУ для медицинской сестры [Электронный ресурс]. - Режим доступу : http:// www.yamedsestra.ru/

7. Пасєчко Н.В.Основи сестринськоїсправи:курс лекцій / Н. В. Пасєчко. - Тернопіль : Укрмедкнига, 1999. - 496 с.

8. Охорона праці в умовах ФАПу, жіночої консультації, акушерського стаціонару [Електронний ресурс]. - Режим доступу : http://akusherstvo.Itd.ua/aa_1_s_01.html 